\title{
MANFAAT ISTIRAHAT PADA PASCA CEDERA AKIBAT BEROLAHRAGA
}

\author{
Ali Satia Graha \\ Fakultas Ilmu Keolahragaan, Universitas Negeri Yogyakarta, Colombo No. 1, Karangmalang Depok, Sleman, \\ Yogyakarta, Indonesia \\ ali_satiagraha@uny.ac.id
}

\begin{abstract}
Abstrak
Olahraga yang berkembang di masyarakat telah banyak menerima IPTEK sebagai pelengkap dalam setiap melakukan aktivitas olahraga. tetapi banyak masyarakat yang melakukan aktivitas olahraga, tidak terlepas dari cedera akibat melakukan olahraga tersebut. Cedera akibat olahraga berdampak pada aktivitas seharihari dan gangguan tubuh yang lain. Karateristik cedera yang dialami oleh para olahragawan seperti cedera ringan, sedang dan berat Cedera pada olahragawan dapat dikelompokkan yaitu cedera derajat-1, cedera derajat-2 dan cedera derajat-3. Cedera derajat-2 dan cedera derajat-3 pada umumnya dilakukan pengobatannya oleh dokter oleh karena cedera derajat-2 dan cedera derajat-3 biasanya jaringan otot robek atau patah tulang, dll. Macam cedera yang tejadi pada tubuh seperti: tulang, otot, ligamen dan persendian anggota gerak tubuh, baik olahraga body contact ataupun non body contact. Cedera yang terjadi tidak dihiraukan oleh para olahragawan dan mereka masih tetap berlatih, bertanding ataupun melakukan aktivitas olahraga untuk prestasi, hobi ataupun kebugaran. Saat cedera terjadi para olahragawan tidak mau untuk beristirahat supaya pulih dari cederanya. Dampak dari tidak adanya istirahat yang terprogram mengakibatkan proses peradangan timbul kembali, kelemahan pada otot semakin tinggi, kreatin kinase meningkat sehingga menimbulkan atrophy otot, dan cedera lama timbul kembali sehingga nyeri terus terasa setiap saat. Kekurangan Kreatin Kinase didalam sarkoplasma otot menyebabkan kemampuan otot menurun tetapi ketika kreatin kinase meningkat akan minimbulkan atrophy pada otot. Istirahat yang terprogram dan cukup sangat penting bagi olahragawan yang mengalami pasca cedera supaya dapat meraih prestasi, kesehatan, kebugaran dan hobi dalam berolahraga kembali.
\end{abstract}

Kata kunci: istirahat, cedera dan olahraga

\section{THE BENEFITS OF REST FOLLOWING INJURED DUE TO SPORTS}

\begin{abstract}
In modern era, sports will engange with science and technology then improving human performance to get achievement, health and recreation through sports. Science and technology used in various sports, on the other hand it causes injured then impact on daily activities. Injury characteristics experienced by athletes such as minor, moderate and severe injuries. Injured can be classified as first-degree injuries, seconddegree injuries and third-degree injuries. Second-degree injuries and third-degree injuries are generally treated by doctors because its usually torn or broken muscle tissue, etc. Types of injuries that occur in the body such as: bones, muscles, ligaments and joints of the limbs, both body contact or non-body contact sports. Sometimes athletes deny that suffers injury and still go the the field for training, compete or do exercise. When the feeling of injury arise, athletes tend to deny the tears and continue their training. Impact of deny to take a rest program will cause inflammation process reappears, weakness in the muscles gets higher, creatine kinase increases, causing muscle atrophy, and overpast injuries reappear so that the pain continues to be felt any time. Creatine kinase decrease in muscle sarcoplasm causing downward muscle ability, while creatine kinase increases, it will generate muscle atrophy. Recovery program is important for


athletes who suffering injured so that he/she should come back to the field to get achievement, health, fitness and passion in sports.

Keywords: rest, injury, sports.

\section{PENDAHULUAN}

Era modern pada olahraga tidak terlepas dari Ilmu Pengetehuan dan Teknologi (IPTEK) serta peningkatan Sumber daya manusia dalam meraih prestasi, kesehatan maupun rekreasi melalui olahraga. uangkapan diatas diperkuat oleh Giriwijoyo dan Sidik (2013: 2) bahwa kesehatan olahraga telah selaras dengan rumusan dari WHO yaitu pembinaan mutu sumber daya manusia menuju sehat seutuhnya.

Olahraga yang berkembang di masyarakat telah banyak menerima IPTEK sebagai pelengkap dalam setiap melakukan aktivitas olahraga. tetapi banyak masyarakat yang melakukan aktivitas olahraga, tidak terlepas dari cedera akibat melakukan olahraga tersebut. Cedera akibat olahraga berdampak pada aktivitas sehari-hari dan gangguan tubuh yang lain. Seperti yang di ungkapkan oleh Becker. J. (2007: 167). Cedera dapat timbul dikarenakan adanya kesalahan gerak ataupun benturan pada waktu melakukan aktivitas olahraga.

Karateristik cedera yang dialami oleh para olahragawan seperti cedera ringan, sedang dan berat (Wijanarko, dkk, 2012: 48). Macam cedera yang tejadi pada tubuh seperti: tulang, otot, ligamen dan persendian anggota gerak tubuh, baik olahraga body contact ataupun non body contact. Seperti yang di ungkapkan oleh Purba (2014: 24), bahwa olahraga body contact dan non body contact sering terjadi cedera anggota tubuh seperti: pada tulang mengalami fraktur, sprain pada ligamen, strain pada otot, dislokasi sendi dan gegar otak yang diakibatkan benturan dan kesalahan gerak pada olahragawan.

Cedera yang dialami memerlukan penanganan yang khusus dan terprogram untuk pemulihan dan kesembuhannya. Tetapi Cedera yang terjadi tidak dihiraukan oleh para olahragawan dan mereka masih tetap berlatih, bertanding ataupun melakukan aktivitas olahraga untuk prestasi, hobi ataupun kebugaran. Saat cedera terjadi para olahragawan tidak mau untuk beristirahat supaya pulih dari cederanya. Dampak dari tidak adanya istirahat yang terprogram mengakibatkan proses peradangan timbul kembali, kelemahan pada otot semakin tinggi, kreatin kinase meningkat sehingga menimbulkan atrophy otot, dan cedera lama timbul kembali sehingga nyeri terus terasa setiap saat. Kekurangan Kreatin Kinase didalam sarkoplasma otot menyebabkan kemampuan otot menurun tetapi ketika kreatin kinase meningkat akan minimbulkan atrophy pada otot (Candow, 2011: 3).

Istirahat yang terprogram dan cukup sangat penting bagi olahragawan yang mengalami pasca cedera supaya dapat meraih prestasi, kesehatan, kebugaran dan hobi dalam berolahraga kembali. Pengertian arti Istirahat secara harafiah adalah suatu kondisi yang tenang, rileks tanpa ada stres emosional, bebas dari kecemasan (Tasya, 2011: 5). Calder (2000: 10) istirahat dalam melakukan olahraga memiliki durasi waktu pemulihan untuk sistem proses biokimia tubuh dalam setiap sesi latihan atau setelah latihan antara lain: (1) sistem pembentukan atau pengisian ATP-PC memerlukan waktu pemulihan 2-5 menit, (2) sistem penghilangan asam laktat memerlukan pemulihan 30-60 menit secara aktif dan secara pasif 60-120 menit, dan (3) sistem pembentukan glikogen otot memerlukan waktu hingga 48 jam. Pendapat lain Waktu istirahat yang optimal dalam seminggu memerlukan 1 sampai 2 hari supaya seluruh organ tubuh mengalami semua perbaikan fungsi-fungsi fisiknya dan di fase istirahat tubuh dapat menyerap kerja oksigen lebih 


\section{MEDIKORA, Vol. XVIII No. 1 April 2019 - 51}

Ali Satia Graha

maksimal sehingga kembali bugar. Macam istirahat yang dilakuakan yaitu tidur, rekreasi, olah tubuh (yoga dan maditasi), dan melakukan masase seluruh tubuh (Tasya 2011: 12).

Pembahasan singkat diatas memberikan wawasan bahwa pentingnya olahraga, pengetahuan tentang cedera dan manfaat istirahat dalam melakukan aktivitas olahraga atau pasca cedera harus diperhatikan dan terprogram. Maka penulis akan membahan lebih dalam tentang manfaat istirahat pada pasca cedera akibat olahraga.

\section{Olahraga}

Olahraga di era modern sekarang ini, merupakan aktivtas yang menyenangkan dan didalamnya ada unsur permainan, prestasi dan kesehatan serta kebugaran tubuh. Olahraga adalah serangkaian olahraga yang teratur dan terancana untuk memelihara gerak dan meningkatkan kemampuan gerak agar bisa mempertahankan hidup dan meningkatkan kualitas hidup. Olahraga merupakan kegiatan yang dapat dilihat dari berbagai aspek sudut pandang seperti aspek jasmani, rohani, sosial budaya dan ekonomi. Giriwijoyo dan Sidik (2012: 36) olahraga adalah serangkaian gerak raga yang teratur dan terencana yang dilakukan orang dengan sadar untuk meningkatkan kemampuan fungsional. Olahraga terbagi menjadi 4 jenis yaitu olahraga prestasi, olahraga rekreasi, olahraga kesehatan dan olahraga pendidikan. Keempat jenis olahraga tersebut tidak terlepas dari masalah kesehatan yang memerlukan upaya kesehatan berupa preventif dan kuratif dalam setiap penyelenggaraannya oleh karena itu olahraga kesehatan penting sekali untuk mendukung prestasi, rekreasi dan pendidikan. Preventif dan kuratif dalam olahraga sangat penting untuk menghindari dari cedera atau menimbulkan kembali cedera yang lama (Graha dan Prioyono 2009: 25).

Peran olahraga kesehatan sangat penting untuk mendukung bagi para olahragawan untuk melakukan aktivitasnya yang aman, sehat dan selalu bugar. Olahraga kesehatan bertujuan untuk merangsang pertumbuhan dan perkembangan jasmani, rohani dan sosial menuju sejahtera sepajang masa. Sepeti konsep WHO yaitu sasaran olahraga kesehatan adalah kemandirian dalam peri kehidupan bio-psiko-sosiologik (Giriwijoyo dan Sidik 2012: 39). Olahraga di masyarakat yang beragam jenis dan macam serta tujuannya mulai dari prestasi, hobi ataupun untuk kebugaran banyak mengalami cedera akibat berolahraga. Faktor-faktor penyebab terjadinya cedera olahraga antara lain, faktor dari dalam yaitu: pemberian metode latihan yang salah, teori latihan yang salah, sarana prasarana tidak lengkap, jenis olahraga. Sedangkan faktor luar penyebab cedera yaitu: pengaruh keluarga, kondisi lingkungan, penyakit yang di derita, kelainan pada anatomis, fisiologis.

Pernyataan pendapat para ahli di atas dapat disimpulkan bahwa setiap melakukan olahraga perlu adanya perencanaan dan pelaksanaan program-program latihan dengan tujuan yang jelas, olahraga yang terukur dan upaya-upaya preventif dan kuratif untuk bermanfaat dalam setiap melakukan aktivitas olahraga tersebut.

\section{Cedera}

Cedera olahraga adalah cedera yang disebabkan oleh kesalahan gerak yang dilakukan saat berolahraga itu sendiri (Giriwijaya dan Sidik, 2013: 6). Cedera olahraga adalah cedera yang terjadi pada otot, serta rangka tubuh dan menimbulkan sistem peradangan dengan diketahui secara patofisiologi yaitu timbul pembengkakan, nyeri, peningkatan suhu, warna, dan penurunan fungsi (Arofa, 2010). Timbulnya cedera ini dapat diakibatkan adanya kesalahan gerak atau benturan pada waktu melakukan aktivitas olahraga (Becker. J., 2007: 168). Seperti yang di ungkapkan oleh Purba (2014: 24), bahwa olahraga body contact dan non body contact sering terjadi cedera anggota tubuh seperti: pada tulang mengalami fraktur, sprain pada ligamen, strain pada otot, dislokasi sendi dan 
gegar otak yang diakibatkan benturan dan kesalahan gerak pada olahragawan. Sedangkan jenis cedera pada olahraga menurut Taylor (2002: 63) dapat berupa: nanar, memar atau hematoma, luksasi, sprain, strain, patah tulang, pendarahan pada kulit, pingsan, dan lain-lain. Pendapat lain menurut Graha dan Priyonoadi (2009: 16) Macam-macam cedera yang terjadi dalam aktifitas sehari-hari maupun dalam berolahraga dibagi menjadi 2: yaitu cedera ringan dan cedera berat yang dijabarkan sebagai berikut: (1) Cedera ringan yaitu cedera yang terjadi karena tidak ada kerusakan yang berarti pada jaringan tubuh, misalnya kekakuan otot dan kelelahan. Cedera ringan tidak memerlukan penanganan khusus, biasanya dapat sembuh sendiri setelah istirahat, (2) Cedera berat yaitu cedera serius pada jaringan tubuh dan memerlukan penanganan khusus dari medis, misalnya robeknya otot, tendon, ligamen atau patah tulang. Cedera pada olahragawan dapat dikelompokkan oleh Hadmisari, dkk (2010: 57) yaitu cedera derajat-1, cedera derajat-2 dan cedera derajat-3. Cedera derajat-2 dan cedera derajat-3 pada umumnya dilakukan pengobatannya oleh dokter oleh karena cedera derajat- 2 dan cedera derajat-3 biasanya jaringan otot robek atau patah tulang, dan lain-lain.

Jika dilihat dari penjelasan di atas, maka cedera olahraga berdampak pada otot, tendon, ligamen dan tulang. Menurut Priyonoadi (2006: 26), ada dua jenis cedera pada otot atau tendo dan ligamentum, yaitu: Pertama, sp Sprain adalah cedera pada ligamentum, cedera ini yang paling sering terjadi pada berbagai cabang olahraga. Sprain adalah cedera pada sendi dengan terjadinya robekan pada ligamentum, hal ini terjadi karena stres berlebihan yang mendadak atau penggunaan berlebihan yang berulang-ulang dari sendi. Berdasarkan berat ringannya cedera, menurut Bambang Priyonoadi (2006: 25), membagi sprain menjadi tiga tingkatan, yaitu a) Sprain Tingkat I. Cedera ini terdapat sedikit hematoma dalam ligamentum dan hanya beberapa serabut yang putus. Cedera menimbulkan rasa nyeri tekan, pembengkakan dan rasa sakit pada daerah tersebut; b) Sprain Tingkat II. Cedera ini lebih banyak serabut dari ligamentum yang putus, tetapi lebih separuh serabut ligamentum yang utuh. Cedera menimbulkan rasa sakit, nyeri tekan, pembengkakan, efusi (cairan yang keluar) dan biasanya tidak dapat menggerakkan persendian tersebut; c) Sprain Tingkat III. Cedera ini seluruh ligamentum putus, sehingga kedua ujungnya terpisah. Persendian yang bersangkutan merasa sangat sakit, terdapat darah dalam persendian, pembekakan, tidak dapat bergerak seperti biasa dan terdapat gerakan-gerakan yang abnormal.Cedera yang terjadi sprain pada ligamen terdapat juga cedera pada otot dan tendo yang biasa dalam medis disebut strain.

Kedua adalah Strain. Strain adalah kerusakan pada suatu bagian otot atau tendo karena penggunaan yang berlebihan ataupun stres yang berlebihan (Graha, 2009: 28). Sedangkan berdasarkan berat ringannya cedera, menurut Priyonoadi (2010: 8), membedakan strain menjadi 3 tingkatan, yaitu: a) Strain Tingkat I: terjadi regangan yang hebat, tetapi belum sampai terjadi robekan pada jaringan muscula tendineus; b) Strain Tingkat II: terdapat robekan pada unit musculo tendineus. Tahap ini menimbulkan rasa nyeri dan sakit sehingga kekuatan berkurang, c) Strain Tingkat III: terjadi robekan total pada unit musculo tendineus. Biasanya hal ini membutuhkan tindakan pembedahan.

Gejala yang timbul akibat cedera dapat berupa peradangan. Seperti yang diungkapkan Hadmisari, dkk (2010: 13), peradangan merupakan mekanisme mobilisasi pertahan tubuh dan reaksi fisiologis dari jaringan rusak baik akibat tekanan mekanis, kimiawi, panas, dingin dan invasi bakteri. Radang mempunyai tujuan memproteksi area yang cedera dan melayani proses penyembuhan. Diperjelas oleh Graha dan Priyonoadi (2009: 18), bahwa tanda-tanda peradangan pada cedera jaringan tubuh yaitu:1) Kalor atau panas karena meningkatnya aliran darah ke daerah yang mengalami cedera; 2) Tumor atau bengkak disebabkan adanya penumpukan cairan pada daerah sekitar jaringan yang cedera; 3) Rubor atau merah pada bagian cedera karena adanya 
pendarahan; 4) Dolor atau rasa nyeri, karena terjadi penekanan pada syaraf akibat penekanan baik otot maupun tulang; 5) Functiolaesa atau tidak bisa digunakan lagi, karena kerusakannya sudah cedera berat.

Ada banyak cedera pada bagian otot. Berikut ini menurut Santosa, (2012: 243).adalah beberapa cedera yang sering terjadi pada otot. 1) Pegal otot (muscle soreness). Setelah bekerja cukup berat dalam waktu yang lama, dapat terjadi tidak hanya kelelahan local, tetapi pegal otot. Pegal otot ini biasanya tidak timbul segera setelah latihan berakhir, tetapi timbul beberapa jam kemudian, dan dapat berlangsung beberapa hari.Pegal otot terjadi karena putusnya beberapa serabut otot akibat latihan olahraga yang berlebih. Pegal otot dapat terjadi akibat latihan yang terlalu lama mengakibatkan tertimbunnya samapah metabolism dalam jumlah yang berlebihan, yang mengakibatkan meningkatnya tekanan osmotic di dalam dan di luar sel-sel otot. Peningkatan tekanan osmotic ini selanjutnya akan mengakibatkan banyaknya air yang tertimbun sehingga terjadi endema (pembengkakan), yang selanjutnya akan menekan saraf-saraf sensori maka akan terjadi pegal otot; 2) Kejang otot (muscle cramps). Kejang otot adalah kontraksi pada satu atau beberapa otot yang terjadi dengan tiba-tiba, kuat, berlangsung lama, dan terasa sakit.

Pembahasan cedera dari para pakar di atas telah jelas bahwa olahraga pada prestasi, kesehatan. Pendidikan dan rekraesi yang tidak terprogram, terukur dan tidak menerapkan IPTEK olahraga akan mengakibatkan cedera semakin akut dan kambuh kembali, sehingga mengganggu aktivitas selanjutnya dan mengalami kecacatan yang permanen.

\section{Istirahat}

Istirahat adalah suatu kondisi yang tenang, rileks tanpa ada stres emosional, bebas dari kecemasan (Tasya, 2011: 5). Istirahat yang diberikan pada tubuh dari aktivitas dapat meningkatkan metabolisme tubuh secara optimal. Seperti hasil penelitian Prasetyo dan Andiana (2012: 1) bahwa latihan interval istirahat aktif lebih baik untuk menanggulangi stres oksidatif dibandingkn latihan interval istirahat pasif.

Istirahat sangat penting bagi atlet atau olahragawan setelah melakukan aktivitas olahraga berat maupun ringan. Seprti yang di ungkapkan oleh Calder (2000: 5) Istirahat ada dua jenis yaitu istirahat aktif dan pasif. Istirahat aktif adalah suatu istirahat dengan melakukan aktivitas fisik ringan pada jeda sesi latihan bisa dengan jalan-jalan ringan atau dengan stretching ringan. Sedangkan istirahat pasif adalah suatu istirahat tanpa melakukan aktivitas apapun untuk memulihkan penumpukan asam laktat seperti melalkukan istirahat berupa tidur atau menikmati suasana alam. Seperti dalam penelitian Fadhli (2014: 44) bahwa Istirahat dalam jeda tiap set latihan bertujuan untuk mengembalikan energi yang terbuang dan penurunan asam laktat pada saat penampilan set yang sebelumnya. Istirahat merupakan sesuatu hal yang sangat kritis untuk menghindari pengaruh dan tekanan fisiologi yang dapat menimbulkan cedera pada otot atau sendi untuk melakukan set berikutnya. Selain itu apabila terjadi cedera akan mengpengaruhi sistem energi khususnya peningkatan pada kreatin kinase.

Berdasarkan hal ini, para ahli mulai mempertimbangkan atau mencari parameter yang lebih cepat dan akurat melalui pengukuran kreatin kinase pada plasma darah. Peningkatan ini dapat menggambarkan adanya kerusakan pada otot. Yang kemungkinan hal ini dapat memprediksi kerusakan pada otot pergelangan kaki dan lutut. Kekurangan Kreatin Kinase didalam sarkoplasma otot menyebabkan kemampuan otot menurun (Candow, 2011: 3). Sedangkan menurut Roeteret (2009: 35) jenis istirahat ada 2 yaitu: (1) istirahat dalam suatu pertandingan, (2) istirahat antar pertandingan dalam suatu kompetisi. Macam Istirahat dalam suatu pertandingan diantaranya yaitu: istirahat pasif, stretching dinamik, permainan ringan, hidrasi cairan elektrolit dan suplementasi 
kreatin. Sedangkan pada istirahat antar pertandingan dalam suatu kompetisi yaitu: istirat pasif, stretching, masase, hidrasi cairan elektrolit, suplementasi creatinin. Dalam penelitian Alim (2012: 102) diketahui bahwa istirahat dalam suatu pertandingan dan istirahat antar pertandingan dalam suatu kompetisi terbukti memenuhi uji kemanfaatan dapat meningkatkan stabilitas performa fisik, performa mental, dan ketrampilan atlet tenis.

Istirahat dalam melakukan olahraga menurut Calder (2000: 10), memiliki durasi waktu pemulihan untuk sistem proses biokimia tubuh dalam setiap sesi latihan atau setelah latihan antara lain: (1) sistem pembentukan atau pengisian ATP-PC memerlukan waktu pemulihan 2-5 menit, (2) sistem penghilangan asam laktat memerlukan pemulihan 30-60 menit secara aktif dan secara pasif 60-120 menit, dan (3) sistem pembentukan glikogen otot memerlukan waktu hingga 48 jam. Pendapat lain Waktu istirahat yang optimal dalam seminggu memerlukan 1 sampai 2 hari supaya seluruh organ tubuh mengalami semua perbaikan fungsi-fungsi fisiknya dan di fase istirahat tubuh dapat menyerap kerja oksigen lebih maksimal sehingga kembali bugar. Macam istirahat yang dilakuakan yaitu tidur, rekreasi, olah tubuh (yoga dan maditasi), dan melakukan masase seluruh tubuh (Tasya 2011: 12).

Pemeparan tentang istirahat dalam olahraga maupun pasca cedra olahraga sangat diutamakan untuk pemulihan tubuh baik secara fisik maupun fisiologis dan psikologis olahrawan ataupun atlet sehat dan bugar kembali.

\section{SIMPULAN}

Olahraga yang berkembang di masyarakat telah banyak menerima IPTEK sebagai pelengkap dalam setiap melakukan aktivitas olahraga. tetapi banyak masyarakat yang melakukan aktivitas olahraga, tidak terlepas dari cedera akibat melakukan olahraga tersebut. Maka dalam kesimpulan ini penulis menyimpulkan antara lain: 1) Olahraga prestasi, kesehatan dan pendidikan harus di dukung oleh perencanaan dan program yang baik dan menerapkan IPTEK untuk tidak terjadi cedera; 2) Cedera akibat olahraga berdampak pada aktivitas sehari-hari dan gangguan tubuh yang lainnya; 3) Aktivitas olahraga ataupun pasca cedera sangat penting menerapkan program istirahat yang tepat dan teratur untuk mencegah terjadi cedera dan atau mempercepat pemulihan cedera pada olahragawan ataupun atlet.

Oleh karena itu diharapkan melakukan olahraga yang benar dan terprogram serta menerapkan IPTEK dalam melakukannya akan mengurangi resiko cedera. Kemudian, olahragawan ataupun atlet dalam pasca cedera akibat olahraga, harus mengutamakan istirahat untuk pemulihan cedera tersebut.

\section{DAFTAR PUSTAKA}

Alim, A. dkk. (2012). Penerapan Teknik Recovery Terintegrasi untuk Peningkatan Stabilitas Performa Fisik, Mental, dan Teknik Atlet Tenis. Jurnal iptek olahraga. Vol 14, no 2, MeiAgustus 2012. ISSN: 1411-0016. Jakarta.

Andiana, O. dan Prastyo, Y. (2009). Buletin penelitian sistem kesehatan. Vol 14, no 2 Juli 2011. ISSN 1410-2935. Terakreditasi A; LIPIno 17/AU/P2MBI/08/2009. Surabaya.

Arofa, N.I. (2010). Dasar-dasar fisioterapi pada Cedera Olahraga. Yogyakarta: FIK UNY.

Becker. J. (2007). Massage therapy for own self. Jakarta. Prestasi Pustakakarya. Hal. 168.

Calder, Angela. (2000). Recovery Training. Australia: Australian Sport Commision.

Candow, D.G. (2011). Sarcopenia: current theories and the potential beneficial effect of creatine application strategies. Canada: Journal. Biogerontology (2011), 12:273-281DOI 10.1007/s 10522-011-9327-6 
Candow, D.G. (2011). Sarcopenia: current theories and the potential beneficial effect of creatine application strategies. Canada: Journal. Biogerontology (2011), 12:273-281DOI 10.1007/s10522-011-9327-6.

Fadhli, N.R. (2014). Jurnal iptek olahraga. Vol 16, no 1, januari - april 2-19) ISSN: 1411-0016. Jakarta

Hadmisari, D., dkk. (2010). Masase olahraga. Jakarta: Kementrian Pemuda dan Olahraga RI.

Giriwijaya dan Sidik. (2013). Ilmu kesehatan olahraga. Bandung: PT. Remaja Rosdakarya. ISBN 978-979-692-085-3 cetakan kedua 3013.

Giriwijoyo, S. (2012). Ilmu faal olahraga (fisiologi olahraga). Bandung: PT. Remaja Rosdakarya.

Graha, A.S. (2009). Pedoman dan Modul Terapi Masase Frirage Penatalaksanaan Terapi Masase dan Cedera Olahraga pada Lutut dan Engkel. Yogyakarta: Klinik Terapi Fisik UNY.

Graha, A.S. dan Priyonoadi, B (2009), Terapi masase frirage penatalaksanaan cedera pada anggota tubuh bagian atas. Yogyakarta: FIK UNY.

Kushartanti, W. (2007). Patofisiologi Cedera Olahraga. Makalah. Yogyakarta: Klinik Terapi Fisik FIK UNY.

Purba, A. (2013).Penerapan FAAL Olahraga untuk Prestasi Atlet. KONI JABAR. ISBN: 478602-19033. Bandung.

Priyonoadi, B. (2006). Sport Massage. Universitas Negeri Yogyakarta: FIK. Yogyakarta.

Roeteret, E. P., Ellenbecker, T.S. dan Reid,M.(2009). Biomechanics of The Tennis Service: Implementation for Strength Training. Strength \& conditioning journal. Vol 31. No. 4 hal. 35.

Taylor, P.M dan taylor, D.K. (2002). Mencegah dan mengatasi cedera olahraga. (Jamal Khalib, Terjemahan). Jakarta: RT. Grafindo Persada.

Tasya. (2011). Pemenuhan kebutuhan istirahat dan tidur. Buletin Artikel kesehatan. Surabaya. Hal: 5-12. surabaya

Wijanarko, B, dkk. (2010). Masase terapi cedera olahraga. Solo: PT. Yuma Pustaka. 